\title{
ВРЕГУЛЮВАННЯ СПОРУ ЗА УЧАСТЮ СУДДІ - ПРИМИРЮВАЛЬНА ПРОЦЕДУРА В ЦИВІЛЬНОМУ СУДОЧИНСТВІ
}

\author{
Татулич І. Ю.
}

\section{ВСТУП}

Першим важливим кроком судової реформи було схвалення Президентом України Стратегії реформування судоустрою та суміжних правових інститутів на 2015-2020 роки ${ }^{1}$. Завершальним етапом судової реформи в Україні стало набуття чинності Закону України «Про внесення змін до Господарського процесуального кодексу України, Цивільного процесуального кодексу України, Кодексу адміністративного судочинства України та інших законодавчих актів» № 2147-VIII від 03.10.2017 року. Оновлені процесуальні кодекси отримали низку нових інститутів, процедур, а чинні норми зазнали змін та доповнень, покликані спростити та прискорити судочинство з цивільних, господарських та адміністративних справ. Адже зростання в судах кількості справ призвело до збільшення навантаженості на суддів, що своєю чергою тягне за собою порушення основних засад цивільного судочинства, недотримання процесуальних строків розгляду справи, затягування процесу, зловживання процесуальними правами учасниками судового процесу, що в кінцевому результаті призводить до ухвалення судом незаконних та необгрунтованих рішень. Перелічені обставини зумовили необхідність пошуку нових спрощених процедур та правил, що забезпечать у майбутньому реалізацію та виконання завдань цивільного судочинства, здійснення ефективного цивільного судочинства, право кожного на справедливий судовий розгляд незалежним та неупередженим судом, зекономить час, процесуальні засоби, судові витрати, зменшить кількість судових засідань тощо.

Ще в травні 2006 року Указом Президента України № 361/2006 «Про Концепцію вдосконалення судівництва для утвердження справедливого суду в Україні відповідно до європейських стандартів» встановлено, що 3 метою розвантаження судів потрібно розвивати альтернативні способи врегулювання спорів, а також створювати умови для стимулювання дешевших і менш формалізованих способів їх урегулювання².

\footnotetext{
${ }^{1}$ Стратегія реформування судоустрою, судочинства та суміжних правових інститутів на 2015-2020 роки. Схвалено Указом Президента України від 20 травня 2015 року № 276. URL: http://zakon5.rada.gov.ua/ laws/show/276/2015.

2 Про концепцію вдосконалення судівництва для утвердження справедливого суду в Україні відповідно до європейських стандартів: Указ Президента України від 10 травня 2006 р. № 361/2006/ Президент України. URL: http://zakon5.rada.gov.ua/laws/show/361/2006.
} 


\section{1. Правова природа процедури врегулювання спору за участю судді}

Одним із низки запроваджених нововведень $є$ інститут врегулювання спору за участю судді (розділ III, глава 4, ст. 201-205 Цивільного процесуального кодексу України (далі - ЦПК України) ${ }^{3}$. Що розуміється під цим нововведенням? Це перш за все вирішення спору між сторонами до початку розгляду справи по суті, за участю судді, доцільність проведення якого вирішується на підготовчому засіданні. Слід зауважити, що такий інститут уже давно діє в зарубіжних країнах, таких як: Австралія, Німеччина, Норвегія, Фінляндія, Болгарія, Хорватія та ін. Причому у деяких країнах такий процес $є$ обов'язковим, в інших добровільним. Так, у Німеччині відбувається від 10000 до 15000 судових медіацій щороку. Однак у Німеччині є судді-медіатори, які проходять обов'язкове навчання з медіації. Процедура судової медіації у них не врегульована до деталей і $є$ досить гнучкою. У Канаді цю процедуру називають «Досудове врегулювання за допомогою судді». Відрізняється модель судової медіації, що запроваджена в Сінгапурі, де для суддівмедіаторів $є$ спеціальне навчання, судді спеціалізуються тільки на медіації та не беруть участі в судових засіданнях. Завдяки цьому у них досить високий показник вирішення спорів - 85 відсотків від загальної кількості пред'явлених позовів.

Якщо проаналізувати функції цього інституту в зарубіжних країнах, то в них врегулювання спору за участю судді вважається медіацією. Проте медіація - це процедура, у якій медіатор сприяє комунікації між сторонами для досягнення консенсусу у розв'язанні конфлікту або вирішенні спору; це приватне урегулювання конфліктів у позасудовому порядку. Натомість врегулювання спору за участю судді базується на компромісах, за яких сторони поступаються своїми позиціями.

Одним із видів медіації називає інститут врегулювання спорів за участю судді О. Можайкіна, виділяючи такі основні критерії: врегулювання спору відбувається за участю третьої (нейтральної сторони), якою є суддя. Так, під час вирішення спору за участю судді владні повноваження останнього полягають у тому, що він затверджує мирову угоду, а також слідкує за тим, щоб не здійснювалося зловживання процесуальними правами сторонами. Тобто така функція судді не може розглядатись як діяльність щодо здійснення правосуддя; до ключових принципів належить конфіденційність та добровільність; вирішення спору здійснюється 3 урахуванням найбільш прийнятних шляхів для сторін (тобто спір вирішується не лише на правових позиціях і в межах предмета позову, а й 3

\footnotetext{
${ }^{3}$ Цивільний процесуальний кодекс України: чинне законодавство зі змінами та допов. станом на 1 лют. 2019 р. (офіц. текст). Київ : ПАЛИВОДА А.В., 2019. 288 с.
} 
урахуванням інтересів сторін); формами проведення процедури є спільні та закриті наради зі сторонами спору; відповідальність за прийняте рішення покладається на сторони спору; суддя, який проводить процедуру врегулювання спору, не має права надавати сторонам юридичні поради та рекомендації та оцінку доказів у справі ${ }^{4}$.

На думку Н. Грень, врегулювання спору за участю судді $є$ присудовою медіацією. За твердженням увченої, присудова медіація є самостійною моделлю медіації, яка інтегрована в судову систему країни ${ }^{5}$.

Як зазначає Т. Цувіна, здійснивши аналіз зарубіжної літератури, можна зробити висновок про те, що є декілька моделей присудової медіації, які склались у світі залежно від того, хто виконує функції медіатора під час проведення присудової медіаційної процедури. Зокрема, можна виділити такі моделі: 1) зовнішня присудова медіація, або «зближена» медіація, чи приватна медіація в межах судового процесу - різновид присудової медіації, за якої суддя передає справу на розгляд медіатору, що вибраний сторонами та не є суддею або іншим працівником суду, а займається наданням медіаційних послуг приватно i зареєстрований як медіатор; 2) внутрішня присудова медіація, або інтегрована медіація - різновид присудової медіації, яка проводиться ніби «всередині» суду його працівниками або суддями-медіаторами та поділяється на два різновиди залежно від того, хто є медіатором: а) проведення медіації іншим суддею суду, де розглядалася справа, який не входить до складу суду, що розглядає зазначену справу; б) проведення медіації працівниками суду, які не $\epsilon$ суддями (наприклад, працівниками апарату суду, помічниками суддів тощо), або спеціальними медіаторами, які працюють у центрі медіації, що знаходиться при суді ${ }^{6}$.

Особливість медіації як альтернативного способу вирішення спору, на думку В. Рєзнікової, полягає в тому, що сторони економічного конфлікту самостійно обирають медіатора, який не ухвалює остаточне рішення для сторін, а сприяє вирішенню конфлікту шляхом організації й проведення примирювальних процедур, зокрема, переговорів так, щоб сторони конфлікту самостійно ухвалили спільне рішення зі спірного питання 7 .

\footnotetext{
${ }^{4}$ Можайкіна О. Правовий аналіз врегулювання спору за участю судді. Зовнішня торгівля: економіка, фінанси і право. 2018. № 2. С. 177-178.

${ }^{5}$ Грень Н.М. Реалізація права людини на справедливий суд шляхом процедури присудової медіації: теоретико-правове дослідження : дис. ... канд. юрид. наук : 12.00.01. Національний університет «Львівська політехніка». Львів. 2017. С. 85.

${ }^{6}$ Цувіна Т.А. Впровадження інституту присудової медіації як перспективний напрям реформування цивільного процесуального законодавства. Україна на иляху до Свропи: реформа ииивільного процесуального законодавства: матеріали Міжнародної науково-практичної конференції. Київ, 2017. C. $195-200$.

${ }^{7}$ Рєзнікова В. Медіація (посередництво) як спосіб вирішення господарських спорів. Вісник Київського національного університету імені Тараса Шевченка. Юридичні науки. 2012. Вип. 90. С. 14.
} 
Тоді як суддя, який врегульовує спір, є тим самим посередником 3 наділенням процесуальних прав та обов'язків представника судової влади. Медіаторами, як правило, виступають особи, що пройшли відповідне навчання і постійно підвищують свій професійний рівень медіатора, тоді як врегулювання спору за участю судді може бути здійснено будь-яким суддею, і жодних додаткових вимог до судді як посередника у вирішенні спору процесуальне законодавство не передбачає. Під час урегулювання спору за участю судді сторони позбавлені права вибору кандидатури посередника, оскільки їхній спір допомагає врегулювати той суддя, який визначений автоматизованою системою документообігу суду 8 .

Тобто фактично з ухваленням змін до ЦПК України було запроваджено судову медіацію як альтернативне вирішення спору, яка має схожі принципи та деякі особливості із мирним урегулюванням спорів у судовому порядку. Впровадження цієї концепції, за якої остання повинна стати повноцінним елементом судових процедур, дало можливість законодавцю визначити іiі однією із стадій судового провадження. Однак, аналізуючи порядок проведення врегулювання спору 3 участю судді, можна дійти висновку, що це скоріш процедура, яка може здійснюватися в межах підготовчого провадження, а саме на підготовчому засіданні, яка детально врегульована нормами цивільного процесуального законодавства та має місце виключно за згоди на це сторін. Між такими процедурами, справді, є спільні ознаки, але і вони не дають підстав ототожнювати ці два самостійні інститути. Спільними $є$ принципи, які реалізуються в цих процедурах; сторони, даючи згоду на їх проведення, можуть будь-коли заявити про розгляд справи за загальними правилами судочинства; як суддя, так і медіатор є незалежними, нейтральними особами; в двох процедурах проводяться наради (спільні, закриті). Однак відмінних ознак між цими процедурами все одно більше, а саме: сутність та процесуальні особливості проведення; завдання суб'єктів, які їх проводять (медіатора і судді); якщо медіатор проходить спеціальне навчання і до цієї посади висуваються певні вимоги, то, на жаль, у вітчизняному судочинстві судді не проходять відповідного навчання і щодо них не встановлено спеціальних вимог; строк проведення аналогічно є різним: якщо класична медіація не $\epsilon$ обмеженою в часі, то врегулювання спору за участю судді обмежене в часі та ін. Ми поділяємо думку С. Сулейманової, яка вважає, що роль медіатора полягає у створенні умов для самостійного знаходження сторонами рішення у своєму спорі. Суддя, на відміну від медіатора,

\footnotetext{
${ }^{8}$ Бутирська I.А. Примирювальні процедури у господарському судочинстві. Сучасні виклики та актуальні проблеми судової реформи в Україні : матеріали 2-ї Міжнар. наук.-практ. конф. (Чернівці, 18-19 жовтня 2018 р.) / редкол.: О.В. Щербанюк (голова), А.С. Цибуляк-Кустевич (відпов. секр.) та ін. Чернівці, 2018. С. 103.
} 
відповідно до положень ЦПК може запропонувати сторонам шлях мирного врегулювання спору. Мета медіації - консенсус на основі концепції winwin, коли результат задовольняє інтереси обох сторін. Мета врегулювання спору за участю судді - компроміс: сторони взаємно поступаються своїми позиціями ${ }^{9}$.

Аналіз норм ЦПК дає підстави виснувати, що наділення судді під час процедури врегулювання спору за участю судді повноваженнями щодо пропонування сторонам можливих шляхів мирного врегулювання спорів не відповідає природі та сутності медіації, а скоріше подібне до консиліації, яка є окремим способом альтернативного вирішення спорів, за якого справа за угодою сторін передається до консиліатора, призначеного за згодою сторін, чия функція - з'ясувати обставини справи об'єктивно та неупереджено та надати конкретні пропозиції для врегулювання спору між сторонами, які не є обов'язковими для сторін. Проте якщо консиліатор вибирається за згодою сторін, то врегулювання спору за участю судді здійснюється суддею, який відкрив провадження у справі. Виходячи із зазначеного, вважаємо, що запропонований у ЦПК інститут врегулювання спору за участю судді не може бути кваліфікований ані як модель присудової медіації, ані як модель присудової консиліації ${ }^{10}$. Ми цілком поділяємо вказану вище позицію, оскільки, вживаючи термін «присудова» медіація, можна зробити висновок про існування в судах окремих осіб медіаторів, які займаються врегулюванням спорів, чого немає в наших судах. Стосовно присудової консиліації, то, справді, ці два інститути мають деякі спільні ознаки. Зокрема, спільна мета - врегулювати конфлікт між сторонами; здійснюються посередником; під час проведення цих процедур реалізуються ті ж самі принципи; суб'єкти - консиліатор і суддя можуть запропонувати сторонам можливий шлях мирного врегулювання спору тощо. Однак якщо консиліатор призначається за згодою сторін, то врегулювання спору за участю судді здійснюється виключно суддею, який відкрив провадження у справі, тобто суддя сторонами не вибирається.

Не вважає врегулювання спору за участю судді медіацією i Л. Романадзе. На думку вченої, це самостійна процедура, яка не має нічого спільного $з$ класичною моделлю медіації. Більш слушно для медіаторів розглядати інститут врегулювання спору за участю судді просто як нову в

\footnotetext{
9 Сулейманова С.P. Врегулювання спору за участю судді та медіація: порівняльно-правова характеристика. Цивільне судочинство у світлі судової реформи в Україні : матеріали Всеукраїнської науково-практичної інтернет-конференції ім. Ю.С. Червоного (Одеса, 13 грудня 2019 р.) / за загальною редакцією д.ю.н., професора Н.Ю. Голубєвої. Одеса : Фенікс, 2019. С. 50. ISBN 978-966-928-474-7.

10 Цувіна Т.А. Перспективи запровадження інституту присудової медіації в Україні. Проблеми циивільного права та процесу : тези доповідей учасників науково-практичної конференції, присвяченої світлій пам'яті Олександра Анатолійовича Пушкіна (м. Харків, 19-20 травня 2017 р.) С. 385.
} 
українській практиці гібридну примирювальну процедуру, що не $\epsilon$ медіацією ${ }^{11}$.

До примирних процедур відносить цей інститут i O. Тиханський, виділяючи специфічні ознаки, що вирізняють цей інститут із-поміж інших альтернативних способів урегулювання спорів і примирних процедур у праві та цивільному процесі: 1) темпоральні межі проведення цієї процедури: а) можливість урегулювати спір за участю судді до початку вирішення справи по суті (ч. 1 ст. 201 ЦПК України); б) здійснення процесу врегулювання в межах розумного строку, проте не більше ніж тридцять днів із дня постановлення ухвали про його проведення; 2) урегулювання спору здійснює суддя, який розглядає справу, у чому вбачаються риси залучення спеціалізованого учасника медіації, що веде переговори. Однак суддя не домовляється зі сторонами, а сприяє їм у врегулюванні спору шляхом з'ясування підстав i предмета спору, роз'ясненням сторонам предмета доказування у справі, здійснення інших дій, спрямованих на мирне врегулювання сторонами спору; 3) дії судді спрямовані на сприяння врегулюванню цивільного спору: він може запропонувати сторонам можливий шлях мирного врегулювання спору (характер переговорів, які має проводити суддя), не надаючи сторонам юридичних консультацій чи оцінки доказів ${ }^{12}$.

Своєю чергою Ю. Притика називає застосування примирних процедур підходом до вирішення юридичних конфліктів з позиції інтересів. Цей спосіб, на думку вченого, грунтується на з'ясуванні та врахуванні взаємних інтересів сторін і спрямований на досягнення взаємовигідної угоди, унаслідок якої жоден учасник конфлікту не програє. Вони постають як альтернатива офіційному правосуддю в судовій системі держави. У західній правовій доктрині їх називають ADR (alternative dispute resolution $)^{13}$.

Як правильно зазначає вітчизняний учений-процесуаліст М. Ясинок, це більш демократична процедура, під час якої можна вказати своє відношення до предмета спору, запропонувати свій вихід зі спірної ситуації, попросити іншу сторону піти на зустріч у тому чи іншому питанні iз рівноцінною щодо цього заміною ${ }^{14}$. О. Тиханський врегулювання

\footnotetext{
${ }^{11}$ Романадзе Л.Д. Сдерживающие недостатки: Какие пробелы в проектах новых ХПК, ГПК и КАС будут мешать примирению сторон судьей или медиатором. Закон и Бизнес. 2017. С. 85.

12 Тиханський О.Б. Місце інституту врегулювання цивільного спору за участю судді в систематиці примирних процедур. Науковий вісник Національної академії внутрішніх справ. 2018. № 2 (107). С. 38.

13 Притика Ю.Д. Теоретичні проблеми захисту прав учасників цивільних правовідносин у третейському суді : дис. ... д-ра юрид. наук : 12.00.03. Київський національний університет імені Тараса Шевченка. Київ, 2006. С. 55.

${ }^{14}$ Цивільний процесуальний кодекс України : науково-практичний коментар / за заг. ред. д. ю. н., професора, академіка Академії наук вищої школи України М.М. Ясинка. Київ : Алерта, 2018. С. 298.
} 
цивільного спору за участю судді розуміє у двох аспектах: як новий цивільно-процесуальний інститут у теорії цивільного права та специфічна процесуальна процедура в межах судового розгляду. Врегулювання цивільного спору за участю судді уособлює в собі всі необхідні риси примирної процедури, проте як специфічна процесуальна процедура також має свої ключові відмінності. Так, цивільний спір не вирішується судом, а врегульовується специфічним компетентним висококваліфікованим посередником - суддею, однак уже не під час здійснення ним судочинства, а під час здійснення низки формальних і неформальних дій, спрямованих на врегулювання цивільного спору в межах права: створити всі необхідні умови для врегулювання цивільного спору із досягненням обопільної згоди сторін у вигляді конкретного рішення, яке затверджується відповідною ухвалою судді, якою спір припиняється по суті ${ }^{15}$.

3 огляду на викладене, можна сміливо поділяти думку Н. Кіреєвої та Є. Приймак, які стверджують, що 3 метою забезпечення ефективної реалізації завдань і цілей процедури врегулювання спору за участю судді необхідно змінити назву глави 4 розділу 3 ЦПК на назву «Судове примирення», вважаючи це самостійною процесуальною процедурою 3 особливими принципами й засобами досягнення, а щодо процесуального статусу судді, який бере участь у врегулюванні спору, використовувати поняття «суддя, який здійснює примирення» ${ }^{16}$.

Таким чином, можна стверджувати, що нині $є$ різні точки зору щодо правової природи інституту врегулювання спору за участю судді. Підсумовуючи викладене, під врегулюванням спору за участю судді слід розуміти самостійну процедуру примирення, яка відбувається в межах судового розгляду, врегульована нормами процесуального законодавства, здійснюється 3 дотриманням спеціальних принципів, з метою примирення сторін та спрямована на спрощення процесуального порядку розгляду та вирішення цивільних справ.

\section{2. Основні принципи та процесуальні особливості інституту врегулювання спору за участю судді як процедури примирення}

Цій процедурі притаманні спеціальні принципи, першим 3 яких $\epsilon$ добровільність. Під добровільністю В. Рєзнікова розуміє прийняття

\footnotetext{
${ }^{15}$ Тиханський О.Б. Врегулювання спору за участю судді у цивільному судочинстві України. Сучасні виклики та актуальні проблеми судової реформи в Україні : матеріали 2-ї Міжнар. наук.-практ. конф. (Чернівці, 18-19 жовтня 2018 р.); / редкол. : О.В. Щербанюк (голова), А.С. Цибуляк-Кустевич (відпов. секр.) та ін. Чернівці, 2018. С. 178.

${ }^{16}$ Кіреєва Н.О., Приймак Є.П. Поняття та правова природа процедури врегулювання спору за участю судді в цивільному процесі України. Науковий вісник Ужгородського наиіонального університету. 2018. Серія ПРАВО. Випуск 48. Том 1. С. 96.
} 
усвідомленого рішення учасниками правових відносин - сторонами процесу - про застосування такої альтернативної процедури розв'язання спору, можливість відмовитися від участі на будь-якому етапі, акцентуючи увагу на тому, що таке рішення не може бути результатом зовнішнього примусу чи активного переконання будь-кого, а повинно бути лише результатом вибору учасників спору ${ }^{17}$. На думку В. Прущак, добровільність сторін проявляється, по-перше, у прийнятті рішення стосовно примирення шляхом вибору такого способу $\mathrm{ABC}$, як врегулювання спору за участю судді, адже ніхто не може застосувати примус до конфліктуючих сторін. По-друге, добровільність того, що відбувається під час процедури врегулювання спору за участю судді-посередника, адже сторони, намагаючись дійти компромісу, самостійно використовують взаємні поступки, вільні у власному волевиявленні стосовно процедури проведення врегулювання спору та можливості iї припинення на будь-якому прийнятному безпосередньо для них етапі. Так, справді, добровільність виступає основним аспектом у такій процедурі, оскільки у разі незгоди учасників, проводитиметься розгляд справи по суті за загальними правилами позовного провадження. Нормативним підтвердженням цього $\epsilon$ ч. 1 ст. 201 ЦПК: «Врегулювання спору за участю судді проводиться за згодою сторін до початку розгляду справи по суті».

Конфіденційність є наступним принципом такої процедури. Надаючи визначення принципу конфіденційності стосовно процедури врегулювання спору за участю судді, слід визначити його як неприпустимість розголошення інформації, що стала відомою безпосередньо під час проведення процедури врегулювання спору за участю судді як учасниками спору, так і суддею-посередником, якщо сторони не домовилися про інакше або цього безпосередньо вимагає закон. Аналізуючи норми чинного законодавства, можна виділити гарантії такої конфіденційності, якими є: ч. 2 ст. 37 ЦПК України, а саме суддя, який брав участь у врегулюванні спору у справі за участю судді, не може брати участі в розгляді цієї справи по суті або перегляді будь-якого ухваленого в ній судового рішення; п. 4 ч. 1 ст. 70 ЦПК України, суддя не може бути допитаний як свідок про обставини обговорення в нарадчій кімнаті питань, що виникли під час ухвалення судового рішення, або про інформацію, що стала відома судді під час врегулювання спору за його участю; ч. 7 ст. 203 ЦПК України, під час проведення врегулювання спору за участю судді протокол наради не ведеться та не здійснюється фіксування технічними засобами; ч. 9 ст. 203 ЦПК України, під час врегулювання спору за участю судді забороняється

17 Рєзнікова В. Медіація (посередництво) як спосіб вирішення господарських спорів. Вісник Київського начіонального університету імені Тараса Шевченка. Юридичні науки. 2012. Вип. 90. С. 11. 
використовувати портативні аудіотехнічні пристрої, а також здійснювати фото- і кінозйомку, відео-, звукозапис; ч. 8 ст. 203 ЦПК України, за необхідності до участі в нарадах залучається перекладач, який попереджається про конфіденційний характер інформації, отриманої під час проведення врегулювання спору за участю судді. Наявність вищеперелічених у законодавстві гарантій конфіденційності можна тільки вітати, оскільки майже у всіх справах сторони не бажають, щоб спір, який між ними виник, був відомий для всіх.

Нейтральність та неупередженість посередника $\epsilon$ ще одним принципом, що характеризує вказану процедуру. Такий принцип окреслює коло тих обов'язків, що покладаються на третю нейтральну сторону, а саме суддю, за участю якого відбувається врегулювання спору. Неупередженість та нейтральність судді-посередника полягає у його незацікавленості у тому чи іншому вирішенні спору, незалежності від будь-якої зі сторін, в обов'язку відсторонитися від власних почуттів, вподобань та переконань, виконувати свої процесуальні обов'язки неупереджено, грунтуючись лише на обставинах справи та думках сторін, не нав'язуючи тим самим їм власну думку. Ми знову ж таки не заперечуємо наявність такого принципу, адже саме неупередженість суду $\epsilon$ міжгалузевим принципом здійснення судочинства, а також одним із завдань цивільного судочинства.

Наступним є принцип гнучкості процедури. Своєрідність усіх видів АВС як інститутів громадянського суспільства, в тому числі і врегулювання спору за участю судді, полягає саме в тому, що на законодавчому рівні не встановлюється чітка структурована система стадій процедур АВС, а лише закріплюються базові засади здійснення певного способу АВС. Це забезпечує своєрідну гнучкість процесу, який, на відміну від судового розгляду, дає змогу дійти сторонам до компромісного взаємоприйнятного вирішення спору.

Неконфронтаційний та неформальний порядок. Такий принцип передбачає відсутність необхідних елементів процесуальної форми та судової атрибутики, що створює психологічний комфорт для учасників та атмосферу довіри ${ }^{18}$.

Досліджуючи процедуру врегулювання спору, К. Шумова розкриває також принцип співробітництва, який відображає приватноправові складники інституту врегулювання цивільного спору за участю судді, i за своїм змістом близький принципу солідарності інтересів і ділового

\footnotetext{
${ }^{18}$ Прущак В.С. Характеристика спеціальних принципів врегулювання спору за участю судді. Новели цивільного процесуального кодексу України : матер. кругл. столу (Одеса, 26 березня 2018 р.) / за заг. редакцією д.ю.н., проф. Н.Ю. Голубєвої; Нац. ун-т «Одес. юрид. акад.». Одеса : Фенікс, 2018. С. $102-105$.
} 
співробітництва. Вважається, що вся процедура примирення, у тому числі судового, повинна бути побудована на взаємних домовленостях, поступках i під час проведення процедури повинні зберігатися атмосфера довіри $\mathrm{i}$ взаємної поваги ${ }^{19}$. Ю. Притика звертає увагу на важливість принципу рівності сторін, який також слід віднести до процедурних принципів врегулювання цивільного спору за участю судді. У широкому розумінні під цим принципом слід уявляти неприпустимість надання привілеїв або застосування обмежень до жодної зі сторін за ознаками будь-якого характеру (майнового, етнічного, соціального, мовного тощо) ${ }^{20}$. Б. Ратушна зазначає, що найкращий процесуальний ефект принципу рівності досягається саме в межах загальної моделі судочинства, збалансовуючи правові можливості сторін у доведенні перед судом своєї правоти і тим самим закладаючи підвалини справедливого розгляду справи ${ }^{21}$. Ми підтримуємо думки науковців, адже прояв цієї засади цивільного судочинства - повага до честі і гідності, рівність перед законом і судом (ст. 6 ЦПК України), полягає в тому, що не повинно бути переваг у процесі врегулювання спору незалежно від раси, кольору шкіри, політичних, релігійних та інших переконань, статі, етнічного та соціального походження, майнового стану, місця проживання, мовних та інших ознак. Рівність повинна бути дотримана під час надання сторонами своїх міркувань, пропозицій, шляхів вирішення спору, доведення своєї позиції на спільних нарадах, відведенням однакової кількості часу для проведення закритих нарад із судом тощо.

Нині однією з ключових проблем на шляху до розбудови України $\epsilon$ проблема реалізації принщипу верховенства права в правотворчій та правозастосовній діяльності. Досить часто звернення суду до принципу верховенства права відбувається суто 3 метою навести додаткову аргументацію своєї правової позиції за умов достатності норми права i створює враження штучності подібних посилань, у тому числі під час урегулювання спору за участю судді ${ }^{22}$.

Окрім наявних у науці ЦПП принципів, на наш погляд, слід виокремити ще один принцип, притаманний цій примирній процедурі, - наявність изивільної проиесуальної форми проведення. Підтвердженням цього є те, що врегулювання спору за участю судді підпорядковане вимогам

\footnotetext{
${ }^{19}$ Шумова К.А. Принципы медиации : дисс. ... канд. юрид. наук. Саратов, 2015. С. 56.

20 Притика Ю.Д. Зміст та класифікація принципів медіації. Бюл. М-ва юстиції Украӥни. 2010. № 10. C. 90 .

21 Ратушна Б.П. Принцип рівності сторін у цивільному процесі України. Митна справа. 2015. № 4(2). С. 100 .

22 Дяченко С.В., Цісар Г.І. Реалізація принципу верховенства права через призму електронного судочинства: теоретичні та практичні підходи. Актуальні проблеми вітчизняної юриспрудениії. 2018. № 6. C. 111-114.
} 
процесуальної форми. Така процедура врегульована нормами процесуального законодавства. Цивільна процесуальна форма - це зумовлена предметом і методом правового регулювання цивільного процесуального права і визначена нормами цивільного процесуального законодавства послідовність виникнення, розвитку i припинення цивільного процесу (судочинства) та порядок реалізації суб'єктами цивільних процесуальних правовідносин своїх процесуальних прав i обов'язків, процесуальних дій, здійснюваних під контролем суду, спрямованих на розгляд i вирішення цивільної справи в суді та процесуального порядку оформлення результатів таких дій ${ }^{23}$.

Таким чином, слід зазначити, що під принципами врегулювання спору за участю судді слід розуміти специфічні засади, ідеї, положення, правові основи, метою яких є забезпечення добровільного та ефективного розв'язання спору, що створюють основу для дій учасників такого процесу та забезпечують індивідуалізацію правового інституту. Разом із тим не всі принципи, закріплені в законодавстві про цивільне судочинство, реалізуються під час впровадження процедури врегулювання спору. Зокрема, принцип гласності, змагальності сторін, фіксації процесу тощо.

Щодо значення цієї примирної процедури, то воно полягає в тому, що перш за все такий інститут спрямований на розвантаження судової системи, тобто зменшується навантаження на суддів через розгляд «дрібних» справ. Також це сприяє швидкості, оперативності вирішення спору на ранній стадії судового процесу. При цьому сторони економлять час, судові витрати. Така процедура сприяє доступності правосуддя, оскільки повертається 50 відсотків судового збору під час врегулювання спору (у разі укладення мирової угоди до прийняття рішення у справі судом першої інстанції, відмови позивача від позову, визнання позову відповідачем). Відбувається руйнування психологічних бар'єрів між сторонами та суддею. Дотримується принцип свободи особистості, адже рішення приймається добровільно, а не нав'язується кимось.

Водночас указаний інститут не позбавлений недоліків, які можуть виникати під час реалізації останнього. По-перше, це спеціальна підготовка самого суддi у проведенні процедури врегулювання спору. Адже для цього їм необхідні спеціальні знання, які не пов'язані із процесуальними діями під час судового розгляду та здійснення правосуддя за загальними правилами. Тому слід забезпечити підготовку суддів відповідної спеціалізації, які матимуть відповідну кваліфікацію на судове врегулювання спору.

\footnotetext{
${ }^{23}$ Татулич І.Ю. Цивільна процесуальна форма в суді першої інстанції в Україні : монографія. Чернівці : Чернівецький нац. ун-т, 2016. С. 47.
} 
По-друге, можемо погодитись із твердженням Л. Романадзе, яка проблему вбачає у мотивації суддів. Вони мають велике навантаження, тому не кожен буде зацікавлений у витрачанні часу (для цього потрібна не одна година) на одну справу замість здійснення правосуддя у звичайний спосіб. Без відповіді залишається питання про те, яким чином участь судді у врегулюванні спору буде враховуватися у визначенні загального навантаження, чи будуть впроваджені додаткові заохочення для суддів, яким вдасться привести сторони до примирення? На думку автора, нав'язування інституту примирення як сторонам, так і суддям викличе опір та буде неефективним ${ }^{24}$.

По-третє, слід врахувати й особистісні якості суддi: уміння спілкуватися із сторонами - суб'єктами спірних правовідносин; бути комунікабельним; володіти морально-етичними якостями; мати певний життєвий досвід, тобто вік судді теж впливатиме на його професійні якості. А звідси велике значення матиме професійна майстерність судді не тільки як юриста, але і психолога, ритора, посередника, організатора тощо.

Цю ж позицію підтримує науковець С. Бондаренко, на думку якої посередник обов'язково має бути знаним фахівцем із предмета спору та неабияким психологом, якому під силу поновити нормальні взаємини між конфліктуючими сторонами та налагодити взаємодію ${ }^{25}$. Т. Подковенко у своїх дослідженнях стверджує, що для належного виконання своєї роботи посереднику необхідно володіти такими рисами, як: уміння слухати, здобуття довіри, вміння подати інформацію, належне використання гумору, відкритість, толерантність, готовність допомогти, організованість та безумовно емоційна зрілість та стабільність, адже важко було би працювати 3 посередником, який не справляється 3 власними проблемами та емоціями ${ }^{26}$.

Доволі проблемним є питання правового статусу судді, який здійснює врегулювання спору. Зі змісту норм ЦПК можна зрозуміти, що кожен суддя має брати участь у врегулюванні спору. У такому разі не враховуються його професійні вміння та навички як посередника, бажання та інші фактори. Запропонована модель урегулювання спору за участю судді не враховує того, що такий суддя, крім знань у галузі права, потребує ще спеціальних навичок та знання психології, соціології, конфліктології тощо. Тому вважаємо за необхідне проводити спеціальні тренінги для

\footnotetext{
24 Романадзе Л.Д. Врегулювання спору за участю судді та інші процесуальні новели: вплив на розвиток медіації. 2017. С. 1-4.

25 Бондаренко С.А. Участники медиативного процесса: гражданско-правовой аспект. Вестник Алтайской академии экономики и права. 2012. № 3. С. 92.

${ }^{26}$ Подковенко Т. Інститут медіації у механізмі правових спорів: основні ідеї та принципи. Актуальні проблеми правознавства. 2017. № 3. С. 39.
} 
таких суддів, постійно підвищувати професійний рівень як суддівпосередників. Альтернативою вирішення цього питання є можливість внесення доповнень до Закону України «Про судоустрій і статус суддів» щодо обрання у кожному суді зборами суддів судді, уповноваженого здійснювати врегулювання спору за участю судді ${ }^{27}$.

По-четверте, це проведення закритих нарад за участю судді з кожною зі сторін окремо. Чи не буде тут ставитись під сумнів дотримання деяких принципів (основних засад) цивільного судочинства, зокрема, незалежність суддів і підкорення їх виключно закону; неприпустимість зловживання процесуальними правами як судом, так і учасниками процесу та ін. Чи є гарантії стосовно питання корупції з боку суду та учасників справи, оскільки хід проведення такої процедури ніде не фіксується, про що йшлося вище.

По-п'яте, це обмежений строк розгляду питання про врегулювання спору, а саме 30 днів (ч. 1 ст. 205). Вважаємо, що для забезпечення ефективності проведення цієї процедури законодавцю не слід було встановлювати такі часові межі, оскільки це може призвести до певного формалізму в судовій практиці. Краще було б зазначити, що такий строк залежить від обставин справи та може бути подовжений, зокрема, на 10 чи 15 днів, про що постановлятиметься ухвала. Наприклад, на це може впливати складність справи, велика кількість учасників процесу, залучення перекладача, об'єднання позовних вимог, неявка сторін 3 поважних причин, завантаженість суддів тощо.

Також зауваження, на наш погляд, заслуговує і питання стосовно строку, протягом якого сторони можуть виявити бажання щодо проведення процедури врегулювання спору, - до початку розгляду справи по суті. 3 огляду на питання та процесуальні дії учасників справи, які там можуть обговорюватись та здійснюватися, видається, що таке право має бути надане сторонам упродовж розгляду справи судом.

Крім того, зміст цієї статті не дає нам чіткої відповіді на питання, хто може бути ініціатором цієї примирної процедури: тільки сторони, які дають свою згоду, чи суддя також може з власної ініціативи запропонувати сторонам врегулювати спір? Вважаємо, що доцільно було б закріпити в цій нормі право судді бути ініціатором цього питання, адже судді притаманна активна роль у цивільному процесі, суд сприяє врегулюванню спору шляхом досягнення угоди між сторонами та сприяє учасникам судового процесу в реалізації ними прав, передбачених Кодексом, відповідно до принципу змагальності (ст. 12 ЦПК). Більше того, внаслідок своєї

\footnotetext{
27 Дяченко С.В., Бичок Т.П. Актуальні питання врегулювання спору за участю судді. Юридичний науковий електронний журнал. 2018. № 6. С. 87.
} 
необізнаності далеко не всі учасники можуть знати про цю процедуру, беручи участь у процесі самостійно без представника. Тому суддя, виступаючи ініціатором, зможе їх детально ознайомити із процесуальним порядком ії проведення.

Критично сприймається і зміст положення ч. 2 ст. 202 ЦПК України, відповідно до якої у разі недосягнення сторонами мирного врегулювання спору за наслідками проведення врегулювання спору за участю судді повторне проведення такої прочедури не допускається. Видається, що введення вказаного обмеження орієнтоване на запобігання зловживанням 3 боку сторін, які гіпотетично можуть затягувати судове провадження численними «зупинками провадження задля спроби примирення». Водночас питання про можливість застосування цієї примирної процедури вирішуе суддя, і він здатен перешкодити зловживанням з боку сторін: відмовити в задоволенні відповідного клопотання або припинити розпочату процедуру відповідно до п. 3 ч. 1 ст. 204 ЦПК України. А от якщо сторони з першого разу не змогли домовитись (що, до речі, $\epsilon$ частим явищем у примирних процедурах), вдруге, навіть за їх спільного свідомого бажання, вони вже не зможуть скористатись допомогою судді для врегулювання спору. Тобто таким чином законодавець краще обмежить сторони у можливості примирення, ніж запобігне зловживанням ${ }^{28}$.

Потребує конкретизації і питання стосовно того, якими правами наділяється суд під час закритих нарад? А саме чи не є надання суддею роз'яснень та пропозицій щодо можливого врегулювання спору та роз'яснень суддею одній зі сторін окремо судової практики в аналогічних справах юридичними порадами та рекомендаціями, які суддя не має права давати? Тобто законодавцю слід було уточнити, що він розуміє під порадами та рекомендаціями судді та за яких умов їх надавати.

Розширенню підлягає і перелік осіб, які можуть бути залучені до прочедури врегулювання спору за участю судді, позаяк законодавець називає тільки перекладача, враховуючи конфіденційний характер інформації. Однак ми вважаємо, що 3 огляду на особливості деяких категорій справ, наприклад, справи щодо дітей, деякі справи окремого провадження, переконує нас про доцільність залучення психолога, органів опіки та піклування тощо.

Зауваження, на наш погляд, викликає і положення щодо того, що у разі припинення врегулювання спору за участю судді з підстав, передбачених п. 1-3 ч. 1 ст. 204 ЦПК, справа передається на розгляд іншому суддi. Вважаємо, що за таких умов сторони, яким не задовольнили клопотання

\footnotetext{
28 Бондаренко-Зелінська Н.Л. Врегулювання спору за участю судді: проблеми та перспективи застосування. Украӥнські наукові записки. 2018. № 67-68. С. 67.
} 
про відвід, ймовірно можуть зловживати своїми процесуальними правами та погоджуватись на проведення такої процедури з метою заміни того чи іншого судді. Тому в юридичній літературі вбачається, що доцільно було б продовжувати слухання справи тим самим суддею. Однак для дотримання принципу конфіденційності передбачена передача справи на розгляд іншому судді у разі продовження розгляду справи по суті. У таких ситуаціях, ймовірно, може йтися про те, що законодавцю слід продумати, в яких випадках справа підлягатиме розгляду тим самим суддею, а в яких розглядатиметься іншим.

\section{ВИСНОВКИ}

Проаналізувавши національне цивільне процесуальне законодавство, норми якого закріплюють процесуальний порядок проведення врегулювання спору за участю судді, можемо дійти висновку, що нормативноправове регулювання зазначеного інституту потребує внесення певних змін та доповнень щодо його вдосконалення з метою його ефективності в цивільному судочинстві. Беззаперечно, що дискусійним $\epsilon$ питання правового статусу судді, який проводить процедуру примирення між сторонами. Залишення без уваги або зволікання з вирішенням окреслених проблем може призвести до нівелювання сутності та значення такого доволі перспективного процесуального інституту, як інституту примирення.

Можемо констатувати, що відсутність єдиних узгоджених теоретичних підходів до визначення цієї процедури породжує деякі суперечності не тільки в науці, а й у практиці його застосування. Звичайно, для ефективного функціонування цього інституту потрібен час, аналіз судової практики інших країн, дієвих механізмів його вдосконалення, що в майбутньому сприятиме реалізації на практиці гарантованого як Конституцією України, так і Конвенцією про захист прав людини і основоположних свобод, іншим національним та міжнародним законодавством права особи на справедливий, неупереджений, своєчасний та ефективний судовий захист порушених, невизнаних або оспорюваних прав, свобод та інтересів, що і $\epsilon$ основоположним завданням правосуддя.

Безумовно, впровадження такої процедури є сміливим кроком уперед до гармонізації національного законодавства із законодавством Європейського Союзу. Поява такого інституту є дієвим засобом, покликаним оптимізувати процесуальний порядок розгляду та вирішення цивільних справ, оскільки дає змогу якісно новими методами досягти однієї з цілей підготовчого засідання - примирення сторін. Введення цієї процедури дає можливість сторонам реалізувати диспозитивні начала в цивільному судочинстві та $€$ 
додатковою гарантією прав та свобод людини і громадянина. Можна сміливо стверджувати, що процедура врегулювання спору за участю судді може стати дієвим та ефективним механізмом, який зменшить навантаження у судах та позитивно вплине на виконання завдань цивільного судочинства. Запроваджена законодавством можливість врегулювання спору за участю судді $\epsilon$ перспективним і прогресивним напрямом до впровадження європейських процедур та норм, а також покращення доступу громадян до суду.

\section{АНОТАЦІЯ}

Статтю присвячено дослідженню інституту врегулювання спору за участю судді у цивільному судочинстві України. Досліджено погляди науковців щодо правової природи цього нововведення. Здійснено порівняльну характеристику цієї процедури 3 іншими примирними процедурами. Проаналізовано принципи, які реалізуються під час впровадження врегулювання спору в судовій практиці. Обгрунтовано, що врегулювання спору за участю судді $\epsilon$ самостійною примирною процедурою в цивільному судочинстві. Висвітлено колізійні питання чинного процесуального законодавства, які закріплюють процесуальний порядок здійснення врегулювання спору за участю судді на національному piвні. Сформульовано висновки та пропозиції, спрямовані на вдосконалення процесуального порядку проведення цієї процедури.

\section{ЛІТЕРАТУРА}

1. Стратегія реформування судоустрою, судочинства та суміжних правових інститутів на 2015-2020 роки. Схвалено Указом Президента України від 20 травня 2015 року № 276/2015. URL: http://zakon5.rada.gov.ua/ laws/show/276/2015.

2. Про концепцію вдосконалення судівництва для утвердження справедливого суду в Україні відповідно до європейських стандартів : Указ Президента України від 10 травня 2006 р. № 361/2006 / Президент України. URL: http://zakon5.rada.gov.ua/laws/show/361/2006.

3. Цивільний процесуальний кодекс України: чинне законодавство зі змінами та допов. станом на 1 лют. 2019 р. (офіц. текст). Київ : ПАЛИВОДА А.В., 2019. 288 с.

4. Можайкіна О. Правовий аналіз врегулювання спору за участю судді. Зовнішня торгівля: економіка, фінанси і право. 2018. № 2. С. 174-180.

5. Грень Н.М. Реалізація права людини на справедливий суд шляхом процедури присудової медіації: теоретико-правове дослідження : дис. ... 
канд. юрид. наук : 12.00.01. Національний університет «Львівська політехніка». Львів. 2017. 250 с.

6. Цувіна Т.А. Впровадження інституту присудової медіації як перспективний напрям реформування цивільного процесуального законодавства. Україна на шляху до Європи: реформа ичивільного процесуального законодавства : матеріали Міжнародної науковопрактичної конференції. Київ, 2017. С. 195-200.

7. Рєзнікова В. Медіація (посередництво) як спосіб вирішення господарських спорів. Вісник Київського начіонального університету імені Тараса Шевченка. Юридичні науки. 2012. Вип. 90. С. 10-15.

8. Бутирська I.A. Примирювальні процедури у господарському судочинстві. Сучасні виклики та актуальні проблеми судової реформи в Україні : матеріали II Міжнар. наук.-практ. конф. (Чернівці, 18-19 жовтня 2018 р.); / редкол. : О.В. Щербанюк (голова), А.С. Цибуляк-Кустевич (відпов. секр.) та ін. Чернівці, 2018. С. 102-105.

9. Сулейманова С.Р. Врегулювання спору за участю судді та медіація: порівняльно-правова характеристика. Цивільне судочинство у світлі судової реформи в Україні : матеріали Всеукраїнської науково-практичної інтернет-конференції ім. Ю.С. Червоного (Одеса, 13 грудня 2019 р.) / за загальною редакцією д.ю.н., професора Н.Ю. Голубєвої. Одеса : Фенікс, 2019. C. 47-50. ISBN 978-966-928-474-7.

10. Цувіна Т.А. Перспективи запровадження інституту присудової медіації в Україні. Проблеми цивільного права та процесу: тези доповідей учасників науково-практичної конференції, присвяченої світлій пам'яті Олександра Анатолійовича Пушкіна (м. Харків, 19-20 травня 2017 р.) C. 383-386.

11. Романадзе Л.Д. Сдерживающие недостатки: Какие пробелы в проектах новых ХПК, ГПК и КАС будут мешать примирению сторон судьей или медиатором. Закон и Бизнес. 2017. С. 85.

12. Тиханський О.Б. Місце інституту врегулювання цивільного спору за участю судді в систематиці примирних процедур. Науковий вісник Національної академії внутрішніх справ. 2018. № 2 (107). С. 31-39.

13. Притика Ю.Д. Теоретичні проблеми захисту прав учасників цивільних правовідносин у третейському суді : дис. ... д-ра юрид. наук : 12.00.03. Київський національний університет імені Тараса Шевченка. Київ, 2006. 632 с.

14. Цивільний процесуальний кодекс України : науково-практичний коментар / за заг. ред. д. ю. н., професора, академіка Академії наук вищої школи України М.М. Ясинка. Київ : Алерта, 2018. 604 с. 
15. Тиханський О.Б. Врегулювання спору за участю судді у цивільному судочинстві України. Сучасні виклики та актуальні проблеми судової реформи в Україні : матеріали II Міжнар. наук.-практ. конф. (Чернівці, 18-19 жовтня 2018 р.) / редкол. : О.В. Щербанюк (голова), А.С. ЦибулякКустевич (відпов. секр.) та ін. Чернівці, 2018. С. 176-178.

16. Кіреєва Н.О., Приймак С.П. Поняття та правова природа процедури врегулювання спору за участю судді в цивільному процесі України. Науковий вісник Ужгородського національного університету. 2018. Серія ПРАВО. Випуск 48. Том 1. С. 94-97.

17. Рєзнікова В. Медіація (посередництво) як спосіб вирішення господарських спорів. Вісник Київського національного університету імені Тараса Шевченка. Юридичні науки. 2012. Вип. 90. С. 10-15.

18. Прущак В.С. Характеристика спеціальних принципів врегулювання спору за участю судді. Новели иивільного процесуального кодексу України : матер. кругл. столу (Одеса, 26 березня 2018 р.) / за заг. редакцією д.ю.н., проф. Н.Ю. Голубєвої; Нац. ун-т «Одес. юрид. акад.». Одеса : Фенікс, 2018. C. $102-105$.

19. Шумова К.А. Принципы медиации : дисс. ... канд. юрид. наук. Саратов, 2015. С. 199.

20. Притика Ю.Д. Зміст та класифікація принципів медіації. Бюл. $M$-ва юстиції України. 2010. № 10. С. 86-92.

21. Ратушна Б.П. Принцип рівності сторін у цивільному процесі України. Митна справа. 2015. № 4(2). С. 98-102.

22. Дяченко С.В., Цісар Г.І. Реалізація принципу верховенства права через призму електронного судочинства: теоретичні та практичні підходи. Актуальні проблеми вітчизняної юриспрудениії. 2018. № 6. С. 111-114.

23. Татулич І.Ю. Цивільна процесуальна форма в суді першої інстанції в Україні : монографія. Чернівці : Чернівецький нац. ун-т, 2016. 192 с.

24. Романадзе Л.Д. Врегулювання спору за участю судді та інші процесуальні новели: вплив на розвиток медіації. 2017. С. 1-4.

25. Бондаренко С.А. Участники медиативного процесса: гражданскоправовой аспект. Вестник Алтайской академии экономики и права. 2012. № 3. С. 92-96.

26. Подковенко Т. Інститут медіації у механізмі правових спорів: основні ідеї та принципи. Актуальні проблеми правознавства. 2017. № 3. C. 39.

27. Дяченко С.В., Бичок Т.П. Актуальні питання врегулювання спору за участю судді. Юридичний науковий електронний журнал. 2018. № 6. C. $86-88$. 
28. Бондаренко-Зелінська Н.Л. Врегулювання спору за участю судді: проблеми та перспективи застосування. Украӥнські наукові записки. 2018. № 67-68. С. 62-70.

Information about author:

Tatulych I. Yu., Ph.D. (in Law), Associate Professor (Private Law), Law Department Yuriy Fedkovych Chernivtsi National University 19 Universytetska Street, Chernivtsi, 58000, Ukraine 